\title{
SCOPE OF RE-UTILIZATION OF WASTE FOUNDRY SAND OBTAINED FROM INDUSTRIAL SECTORS IN AND NEAR KOLHAPUR, MAHARASHTRA TO ACHIEVE SUSTAINABILITY
}

\author{
Arundhati Vijay Shinde \\ SPSMBH's College of Architecture \\ Kolhapur, Maharashtra, India
}

\author{
Ar. Vandana Pusalkar \\ SPSMBH's College of Architecture \\ Kolhapur, Maharashtra, India
}

\begin{abstract}
At re-utilization and self-sustaining aspects have become an important factor to survive as humans and also as a part of nature. The issues that we are facing like climate change, health issues, global warming, pollution, etc. cannot be neglected or taken for granted anymore. Which makes it important to create a sustainable relationship to achieve a balance between manufacturing, consumption, and disposal of every product generated. Reusing industrial waste and recycling it into viable and sustainable solutions to fulfill the upcoming need for resources becomes a substantial solution to the increasing quantity of waste from industries and factories.

This paper focuses on industry waste like waste foundry sand obtained from foundries that can be used effectively. Specifically in the scope of foundry industries in and around Kolhapur, as being a potentially growing foundry industrial hub. So with such a scenario where the waste and its generation occur simultaneously. It demands a sustainable solution. This brings the focus to the model of obvious generation and re-utilization. This paper briefly reviews the opportunity of generating a sustainable solution with waste foundry sand generated in foundry industries and its scope of effective re-utilization. And elaboration about the sustainable approach of the utilization of Industrial waste obtained from the industrial sector in and near Kolhapur, Maharashtra.
\end{abstract}

Keywords - Sustainability, Waste Foundry sand (WFS), Re-utilization, Kolhapur- foundry industries, Sustainable development, Ferrous Foundry

\section{INTRODUCTION}

Any kind of waste generated or by-products that are formed during the process are very impactful on the environment and have their consequences. Because anything that comes in has to go somewhere. And it cannot just be left out as waste. As waste is categorized as hazardous and non-hazardous. Hazardous waste is dangerous and harmful to the environment and India generates more than 1.50 lakh metric tons of waste per day and the sad scenario is that about $80 \%$ of it is dumped and only $20 \%$ is processed [1]. And this is only increasing the mounts on landfill sites. The rate of hazardous waste is increasing by $2-5 \%$ every year and about 74.6 lakh tons of hazardous waste is generated annually in India [2]. Whereas Kolhapur generates about 165MT of waste per day and about 10 MT of Industrial waste is produced per day [3]. These figures highlight the problem which should be rectified effectively.

Industrial waste is the one produced during the manufacturing of different products from factories, mills, mines, industries, etc. This is the waste that is considered waste during the process, and thrown into the dumping grounds or given for treatment. However, we can introduce methods to retreat and reuse this waste in the construction industry. Right now recycling is the most significant step we can use to reduce negative impacts. But the chaos in industrial sectors with no proper solutions or thoughts over the reusing and treatment of waste is common throughout the country. Also, similar conditions can be seen in Kolhapur MIDC areas. More specifically foundry Industries are booming and majorly practiced in Kolhapur Industrial sector. Also, Foundry Industry has been playing a keen and substantial role since the industrial revolution.

India is the second-largest in casting and expected to grow appreciably in the future. As casting production in the year 2018 was about $11 \mathrm{mn}$ tones and will be increasing at a compound annual growth rate (CAGR) of $\sim 12.7 \%$ from 2018 until 2023 [4]. Also, there are about 5000- 7000 foundry units currently in India out them most of them are small scale industries with foundries. Belgaum, Jalandhar, Coimbatore, Kolhapur, Hyderabad, and Rajkot have the major foundry industry sectors [5]. 


\section{International Journal of Engineering Applied Sciences and Technology, 2021 \\ Vol. 5, Issue 9, ISSN No. 2455-2143, Pages 124-128 \\ Published Online January 2021 in IJEAST (http://www.ijeast.com)}

These foundry industries produce the waste sand, waste slug, chemicals, etc. but the waste sand generated is in enormous amount. Annually about 3 million tons of waste foundry sand (WFS) is generated in India through different foundry units [6]. As such amount of waste sand is generated and if not treated properly will be problematic for nature and humans. Here comes the problem with provided solution and scope for sustainable development. As generation and re-utilization of the waste foundry sand allow sustainable development factors in places where enormous foundry industries exist as in Kolhapur.

\section{BACKGROUND}

Current environmental issues, chaos in industrial sectors, and the rise of alarming situations due to negative impact from human activities, clearly depicts that sustainability has become a necessity in every sector. So focusing on foundry industries, that too in Kolhapur sector the two points should be considered that is, the sustainable approach can be worked out by working on the conservation, utilization, and effective disposal factors.

Because foundry Industries use an enormous amount of energy and then also leave behind an enormous amount of residue. This depicts that it's being harmful to the environment even while in the process and also after the process is completed. So when we speak about the sustainable approach it means the whole method and the product should be sustainable. That is achieving sustainability during the process or while making a particular product, while utilizing that, and also the effective disposal of a product after it becomes useless. These key factors are to be achieved to achieve sustainability.

In foundry industries, the scenario is that the sand which is used while casting metals is changed and also recycled several times. But after a certain number of cycles, the sand becomes useless to use in the foundry and becomes waste foundry sand (WFS). As they lose the binding properties due to contact with molten metals at higher degree temperatures [7]. Hence leading to degradation in physical and chemical properties of sand which make it unfit for further use. Then this sand is disposed of with no proper measures resulting in water and air pollution because the foundry dust contains toxic materials and they also go on contaminating water. Another factor of concern is the Carbon factor during the metal melting which involves a tremendous amount of electricity.

And also the energy usage depends on the metals which will be melted and the amount or size of cast components [8]. This environment and the energy consumption issues cannot be neglected and can be commonly related to all foundry industries and not just foundry industries in Kolhapur and India. So recycling the waste foundry sand in the construction industry and effective use of a renewable source of energy can be the substantial support in reducing the harmful and vicious effects that are caused due to foundry industries in that city or area and also on its environment and climate.

\section{METHODOLOGY}

This paper discusses about the re-utilization of industrial waste particularly waste foundry sand. This is to showcase positive attitude towards the re-use of industrial waste. Also concern and awareness towards environmental issue.

In first part of this paper I have done intensive literature review related to industrial foundry waste at general, international and local level. And in second part of this paper it depicts scope over how this waste foundry sand can be reutilized in construction.

\section{LITERATURE REVIEW}

Many different pieces of research and approach have been practiced and discussed in the utilization of waste foundry sand. Disposal of waste foundry sand has been an issue of concern and researchers are always interested to find a more effective solution to these problems. Re-utilization is one of the substantial solutions. But here its scope and later effects and benefits should be considered more appropriately. Many authors have focused on the use of waste foundry industry in civil and construction industries. Considering the chemical, physical, and mechanical properties it is greatly useful as reusable end products. Most opportunities for their reuse can be seen in construction industries and also in agriculture industries [9].

[10] Studies in this paper focus on the idea of using waste material in construction by both means as waste material and also as recycled material in construction industries. It analysis the current strength and materials of the waste that can be recycled and reused as a construction material with effective and valuable solutions and methods. While also focuses on how the utilization of industrial waste decreases our dependency on raw and natural resources.

Foundry sand leaves behind the residue and it is categorized in different particle size that is below $0.1 \mathrm{~mm}$, above $0.6 \mathrm{~mm}$, between $0.1 \mathrm{~mm}$ and $0.6 \mathrm{~mm}$. And the sand size of fractions between $0.1 \mathrm{~mm}$ and $0.025 \mathrm{~mm}$ can be used in the concrete industry in the concrete industry. This was the result obtained by [11] during the economic evaluation of reuse and recycle of waste foundry sand.

In the investigation of reuse and recycling of waste foundry sand, it showcased that $10 \%$ of waste foundry sand replacement in asphalt concrete with aggregate makes it more suitable for asphalt concrete mixture. This was found by [12] during the investigation of waste foundry reuse. And also there is no severe effect of waste foundry sand on the environment.

[13] Investigated that the waste foundry sand can be used as an ingredient in a mixture with topsoil, for landscaping and also reclamation projects. This can be also used in the rooting zone for sports turf. These are some potential uses of waste foundry sand as a blend in soil. Such practices can definitely reduce the disposal problems of waste foundry sand in a harmful manner and simultaneously decreases the harmful impact on the environment. 


\section{International Journal of Engineering Applied Sciences and Technology, 2021 \\ Vol. 5, Issue 9, ISSN No. 2455-2143, Pages 124-128 \\ Published Online January 2021 in IJEAST (http://www.ijeast.com)}

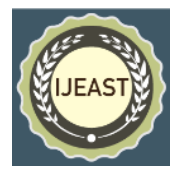

\section{A. Foundry sand:}

Place where metals and alloys are melted and solidified in molds to obtain desired shapes is called foundry and byproduct which is obtained from a casting of ferrous and nonferrous casting is foundry sand or also called WFS( waste foundry sand. Foundry sand contains high-quality silica and is very fine in size [14]. This silica sand is used for making the casting molds. And the sand is used and when reused several times and becomes useless at the end, thus living behind the WFS (waste foundry sand). Which if not disposed of properly is harmful and dangerous. But it can be used effectively and advantageously in the construction industry.

\section{B. Scenario of Foundry Industry in Kolhapur:}

Kolhapur has major foundry industries with a leading manufacturer of quality casting. There are about 300 foundry units in Kolhapur. They are divided into eight industrial estates. They are Kolhapur city, Shiroli MIDC, Gokul Shirgaon MIDC, Kagal 5- Star MIDC, Ichalkaranji Industrial estate, Jaisingpur Industrial area, and Hatkanagale industrial area. With the annual production of about 600,000 tons of castings [15]. These foundries use the sand in the process of casting. Further, after the using and reusing, until the sand becomes useless but when this sand cannot be re-used in the process and gets inefficient to be used it is then dumped out. The quantity of sand that is dumped or becomes useless in the foundry is of large quantity. That useless sand is waste foundry sand which is generated in a very huge amount and becomes a serious disposal issue. As it's the growing industry in India and more specifically in Kolhapur, serious solutions towards the problems and issues needed to be focused on. Another point that needed to be considered is energy consumption and MSME (Ministry of Micro, Small \& Medium Enterprises) [16]. Because most of the units here come under MSME and are the source of employment to many people and households.

Here, when the scenario of the Kolhapur foundry industry is speculated through the scope of sustainability and environmental conditions, it specifically points out the waste generated and energy consumption issues. Because the foundry industries use a tremendous amount of energy, the energy they use cost about $15-20 \%$ of the total cost of production [17]. Also, the foundry waste generated becomes useless after a certain point, and hence also the sand reclamation project in Kolhapur becomes the support for sustainability [18]. But appropriate and effective ways of recycling and reuse have become a requirement of today's severe and harmful issues.

\section{DISCUSSIONS}

Today the world is at the point where we need to stop and think about our practices and change our ways. We are making products for 100 years, and the point comes when we start producing more waste than the real products. In this developing world all the industries try their best and make the best out of them, but simultaneously while doing this, the waste generated is harming the environment and more problems are coming up. So we need to find out a solution for a zero-waste industry system with sustainable solutions. Waste is waste because we call it so.

The different industrial sector generates a huge amount of waste. So we can convert this waste into valuable materials. The most economical and preferable way of treating this industrial waste problem is reusing it by recycling in the construction industry. So the proposed concept is to make the city self-sustaining in the industrial sector, which will automatically increase the other factors which are required for the betterment of the city. Specifically speaking about the Kolhapur city and its foundry waste. Important concern through research and various discussions highlights the reuse of foundry waste and how this will helpful for Kolhapur and its natural and climatic environment.

Following are the aspects if focused and concentrated will be beneficial:

1. Effective reuse and recycling of foundry sand like in making tiles, as a replacement for clay in ceramic tiles, and can enhance the specimen property by $15 \%$.

2. Foundry sand can be used as a partial replacement for fine aggregate in the concrete mix, which can also help in increasing compressive strength. When $10 \%$ of aggregate in the concrete mix is replaced by Waste foundry sand then it enhances the compressive strength and when $20 \%$ of replacement is there then its strength can be compared with referral concrete. This finally also helps in low-cost concrete and hence low-cost construction material [19].

3. Reuse of foundry sand (WFS) as geopolymer building material or called WFS based geopolymer material. Which can be considered as lightweight building material [7] and can be used in construction building walls.

4. The use of renewable energy and appropriate selection of types of machinery and equipment with correct and right operations in a foundry can bolster the sustainable and economic growth of the foundry industry substantially [20].

5. Proper and right maintenance with the right operation of the equipment will help in decreasing the energy consumption numbers which will simultaneously play a major and important role in reducing carbon emission [20].

\section{A. The scenario of the foundry industry at a different level:}

Foundry industries have grown eminently throughout the world and the global casting rate has increased by $2.6 \%$ as compared to the year 2018 with total castings of more than 


\section{International Journal of Engineering Applied Sciences and Technology, 2021 \\ Vol. 5, Issue 9, ISSN No. 2455-2143, Pages 124-128 \\ Published Online January 2021 in IJEAST (http://www.ijeast.com)}

112 million metric tons [21]. India is in the second position and there are about 5000 foundries in India and 90\% of them are Ministry of Micro, Small \& Medium Enterprises and also there are many unregistered foundries. This figures of growth in castings and usually 1 ton of sand is required to cast each ton of iron or steel castings. This it-self showcases the reasons for environmental concerns. These foundry industries use the sand again and again during the processes of casting unless they become completely useless in the foundry. But the residue then which is left behind does not get disposed of properly. And this disposal issue is common throughout the world. And same is the condition in the Kolhapur foundry industry. Then they go on polluting water and air which causes environmental problems.

\section{B. Impact on environment and nature:}

As discussed previously overall scenario of Foundry industries, the residue which is left behind even after using it many times during the process of casting, at a point the sand becomes useless and cannot be used in foundries. Because the sand loose their binding properties due to heating at high temperature.

So the main and foremost concern is about the residue that is left behind which is called waste foundry sand. This sand causes a harmful impact on the environment. And also other concerns are there related to energy conservation and the use of raw resources in abundant amounts. The main impact of the foundry industry on the environment are:

1. Causes water pollution because of improper disposal of waste foundry sand

2. Sand casting is responsible for generating solid waste and sand waste is generated enormously which harms nature.

3. The emission of pollutants causes air pollution and may spread harmful particles in the air.

4. Waste for foundries is in all forms like liquid state, solid-state as sand waste, slag waste, also the gaseous waste.

5. Furnace called cupola makes more pollution than induction furnaces due to the use of coke which pollutes the air around [22].

C. Issues to be concentrated and focused on:

1. Using proper types of machinery and technique to avoid the generation of unnecessary waste. So that amount of waste can be avoided.

2. More efficient techniques to recycle the waste foundry sand.

3. Policies and rules to maintain sustainability in foundry sectors.

4. Working on an efficient model of reuse, recycle, and reduce waste factors.

\section{RECOMMENDATIONS}

Generations of re-utilizations units or models of waste foundry sand with effective solution will be a substantial approach in sustainable way towards foundry industry. Thus, Encouraging and highlighting the scope and opportunities of development through re-use and recycling of waste foundry sand will be useful. Making proper policies and solid regulations regarding re-utilization of foundry sand and making an urge to implement them is most important thing when the rules are made. Another important factor is awareness in people. Inculcating awareness in every person working in foundry regarding the impact of waste foundry sand if not disposed of properly.

\section{CONCLUSION}

This research and investigation showcase the Save- SafeValue factors which will important pillars and bolster foundry industries towards sustainable foundry industries. Herewith the re-utilization approach, the energy is saved, resources are saved, and also material thus saves the environment and also valuable material is generated which will be saving the environment.

Hence the new product will be obtained and also employment will be generated. Everything is processed and valued and there is nothing left like a waste. The processes are ultimately leading to a reduce-reuse-recycle. Which will be simultaneously achieving sustainability and hence helping in reducing the environmental impact, and finally everything helping in supporting earth and human civilization. Reutilization of foundry sand and the positive sustainable approach towards better and self-sustaining foundry industries.

\section{REFERENCES}

[1] R. Shrivastava, "India's Trash Bomb: $80 \%$ of 1.5 lakh metric tonne daily garbage remains exposed, untreated," 21 july 2019. [Online]. Available: https://www.indiatoday.in/india/story/india-s-trash-bomb80-of-1-5-lakh-metric-tonne-daily-garbage-remainsexposed-untreated-1571769-2019-07-21.

[2] "Welcome to Kolhapur Municipal Corporation," Kolhapurcorporation.gov.in.

[3] "Nswai.com".

[4] F. I. Center, (2020) Center of Excellence of The Institute of Indian Foundrymen,. [Online]. Available: http://www.foundryinfoindia.org/price_trends/Default.aspx.

[5] I. Admin, (2020) "The Institute of Indian Foundrymen," Indian Foundrymen Journal, .

[6] S. User, (March 2020)"Characterisation of Foundry Sand Waste Material for Road Construction".

[7] N. Doğan-Sağlamtimur, (2018/05/17) "Waste Foundry Sand Usage for Building Material Production: A First 
Geopolymer Record in Material Reuse",Advances in Civil Engineering - Hindwai, (p. 10 pages, 17).

[8] M. Wänerholm, "Climate impact of metal-casting," Swerea SWECAST, 2016.

[9] A. D. a. Y.-T. Hung, (2014) "REUSE OF FOUNDRY SAND AS CONSTRUCTION MATERIAL," in Handbook of Environment and Waste Management, Vols. volume -2, L. K. W. a. N. K. S. Yung-Tse Hung, Ed, (pp. 491-549).

[10] T. A.-L. a. E. F. Johnny Bolden, (2013) "UTILIZATION OF RECYCLED AND WASTE MATERIALS IN VARIOUS CONSTRUCTION APPLICATIONS," American Journal of Environmental Science, vol. 9 (1),(pp. 14-24).

[11] S. a. M. C. Z. Fiore, (2007) "Foundry wastes reuse and recycling in concrete production," American Journal of Environmental Sciences, 3(3), (pp. 135-142).

[12] R. K. H. \&. D. Bakis, (June 2006) "An investigation of waste foundry sand in asphalt concrete mixtures.", Waste Management \& Research, 24(3),( pp. 269-274).

[13] T. J. L. Billie J Lindsay, (2005) "Agricultural reuse of foundry sand," Journal of residuals science and technology, (vol. 2, pp. 3-12).

[14] J. A.-L. T. \&. F. E. Bolden,( 2013) "Utilization of recycled and waste materials in various construction applications," American Journal of Environmental Science.

[15] 2020.

[Online]. Available: https://sidbi.in/files/posts/Cluster-Profile-Report--Kolhapur-(Foundry)-Cluster.pdf.

[16] R. A. Patil, 2012. [Online]. Available: http://navjyot.net/wp-content/uploads/2014/02/(5058.pdf).

[17] D. R. EN Gopal, (2014)"Resource Efficiency for Sustainability in Ferrous Foundry-A Case of Kolhapur MSME Cluster," Indian Foundry Journal,) pp. 60(2),3039).

[18] C. News, ( 9 june 2016) "Sand reclamation unit to start soon | Kolhapur News - Times of India," Kolhapur News - Times of India.

[19] V. Srivastava, "Utilization of Waste Foundry Sand as Partial Replacement of Fine Aggregate for Low Cost Concrete," International Journal of Current Engineering and Technology, 2015/12/01.

[20] f. i. Center, "Foundry Informatics Centre | Energy Conservation Opportunities - Foundry Industry," 24-112020.

[21] "Modern Casting, (2019) " A publication of the American Foundry Society, no. december 2019 issue.

[22] "Environmental Issues," Themetalcasting.com,
Themetalcasting.com. 